\title{
Balantidium grimi n. sp. (Ciliophora, Litostomatea), a new species inhabiting the rectum of the frog Quasipaa spinosa from Lishui, China
}

Weishan Zhao ${ }^{1,3}$, Can $\mathrm{Li}^{2}$, Dong Zhang ${ }^{1,3}$, Runqiu Wang ${ }^{1,3}$, Yingzhen Zheng ${ }^{4}$, Hong Zou ${ }^{1}$, Wenxiang Li $^{1}$, Shangong $\mathrm{Wu}^{1}$, Guitang $\mathrm{Wang}^{1}$, and Ming $\mathrm{Li}^{1, *}$

${ }^{1}$ Key Laboratory of Aquaculture Disease Control, Ministry of Agriculture, and State Key Laboratory of Freshwater Ecology and Biotechnology, Institute of Hydrobiology, Chinese Academy of Sciences, 430072 Wuhan, PR China

${ }^{2}$ Hubei Key Laboratory of Animal Nutrition and Feed Science, Wuhan Polytechnic University, 430023 Wuhan, PR China

${ }^{3}$ University of the Chinese Academy of Sciences, 100049 Beijing, PR China

4 Animal Husbandry and Aquaculture Station, Agriculture Forestry Animal Husbandry and Aquaculture Bureau of Guye District of Tangshan City, 063100 Tangshan, PR China

Received 27 January 2018, Accepted 1 May 2018, Published online 28 May 2018

\begin{abstract}
Balantidium grimi n. sp. is described from the rectum of the frog Quasipaa spinosa (Amphibia, Dicroglossidae) from Lishui, Zhejiang Province, China. The new species is described by both light microscopy (LM) and scanning electron microscopy (SEM), and a molecular phylogenetic analysis is also presented. This species has unique morphological features in that the body shape is somewhat flattened and the vestibulum is "V"-shaped, occupying nearly $3 / 8$ to $4 / 7$ of the body length. Only one contractile vacuole, situated at the posterior body, was observed. The phylogenetic analysis based on SSU-rDNA indicates that B. grimi groups together with B. duodeni and B. entozoon. In addition, the genus Balantidium is clearly polyphyletic.
\end{abstract}

Keywords: Balantidium grimi, ciliate, new species, Quasipaa spinosa, China

\begin{abstract}
Résumé-Balantidium grimin.sp. (Ciliophora, Litostomatea), nouvelle espèce habitant le rectum de la grenouille Quasipaa spinosa de Lishui, Chine. Balantidium grimin. sp. est décrit à partir du rectum de la grenouille Quasipaa spinosa (Amphibia, Dicroglossidae) de Lishui, province de Zhejiang, Chine. La nouvelle espèce est décrite à la fois par microscopie photonique et électronique à balayage, et une analyse phylogénétique moléculaire est également présentée. Cette espèce possède des caractéristiques morphologiques uniques en ce que la forme du corps est quelque peu aplatie et que le vestibule est en forme de « $\mathrm{V}$ » et occupe près de $3 / 8$ à $4 / 7$ de la longueur du corps. Une seule vacuole contractile, située au niveau du corps postérieur, a été observée. L'analyse phylogénétique basée sur la petite sous-unité de l'ADNr indique que B. grimi forme un groupe avec B. duodeni et B. entozoon. De plus, le genre Balantidium est clairement polyphylétique.
\end{abstract}

\section{Introduction}

The genus Balantidium Claparède \& Lachmann, 1858 consists of many species inhabiting the digestive tract in a wide number of hosts from both invertebrate and vertebrate animals as endocommensals. They are generally considered harmless, but factors depressing the resistance of the host enable them to invade the mucosa and cause ulceration. The representatives of Balantidium have some common morphological features: cell body sacciform or slightly elongated in shape, and completely covered with cilia forming dense longitudinal rows [21]. To

\footnotetext{
*Corresponding author: liming@ihb.ac.cn.
}

our knowledge, 31 amphibian balantidial species have been reported so far (lists in Li et al. [20]).

To date, 27 valid species have been reported in anuran amphibians, including B. amygdalli Bhatia \& Gulati, 1927 [3], B. aurangabadensis Shete \& Krishnamurthy, 1984 [34], B. bicavata Bhatia \& Gulati, 1927 [3], B. claperedei Mahoon \& Khan, 1986 [22], B. corlissi Shete \& Krishnamurthy, 1984 [34], B. cyanophlycti Shete \& Krishnamurthy, 1984 [34], B. duodeni Stein, 1867 [36], B. elongatum Stein, 1867 [36], B. entozoon Ehrenberg, 1838 [9], B. falciformis Walker, 1909 [40], B. ganapatii Shete \& Krishnamurthy, 1984 [34], B. giganteum Bezzenberger, 1904 [2], B. gracile Bezzenberger, 1904 [2], B. helenae Bezzenberger, 1904 [2], B. honghuensis Li et al., 2013 [18], B. kirbyi Rodriguez, 1939 [31], B. megastomae 
Shete \& Krishnamurthy, 1984 [34], B. mininucleatum Shete \& Krishnamurthy, 1984 [34], B. ranae Shete \& Krishnamurthy, 1984 [34], B. ranarum Ghosh, 1921 [10], B. rotundum Bezzenberger, 1904 [2], B. sinensis Nie, 1935 [24], B. singaporensis Khan \& Ip, 1986 [16], B. sushilii Ray, 1932 [30], B. tigrinae Shete \& Krishnamurthy, 1984 [34], B. vanensis Senler \& Yildiz, 2000 [33] and B. xenopi Puytorac \& Grain, 1965 [28]. Five other balantidial species were found in urodele amphibians, including B. amblystomatis Jírovec, 1930 [15], B. andianusis Li et al., 2008 [20], B. elongatum Stein, 1867 [36], B. rayi Pal \& Dasgupta, 1978 [25] and B. tylototritonis Pal \& Dasgupta, 1978 [25]. Among the aforementioned species, 3 balantidial species inhabiting amphibians were first discovered and named in China. B. andianusis was reported in the Chinese giant salamander, Andrias davidianus [20]; B. sinensis was described from 2 species of anuran amphibians and 1 urodele amphibian, $R$. nigromaculata, $R$. plancyi [24] and A. davidianus [20], respectively, and $B$. honghuensis was found in $R$. nigromaculata [18].

Although many amphibian Balantidium species have been reported, few molecular data are available at present (only two species B. entozoon and B. duodeni have corresponding SSU-rDNA sequences in NCBI). Even less is known about phylogenetic relationships between different balantidial groups inhabiting different hosts (such as fishes, amphibians, mammals, etc.).

In the present study, a new Balantidium species inhabiting Quasipaa spinosa is described based on detailed light and scanning electron microscopy observation. This is also the first record of Balantidium species in the digestive tract of Quasipaa spinosa. Phylogenetic analysis based on SSU-rDNA was also carried out to reveal the relationships among Balantidium species as well as different clades of Trichostomatia.

\section{Materials and methods}

\subsection{Specimen collection and identification}

The frogs used for this study were captured from Lishui City $\left(27^{\circ} 25^{\prime}-28^{\circ} 57^{\prime} \mathrm{N}, 118^{\circ} 41^{\prime}-120^{\circ} 26^{\prime} \mathrm{E}\right)$, Zhejiang Province, southeast China in August, 2017. We obtained permits allowing us to capture and sacrifice these specimens. The frogs were transported alive to the laboratory, then all frog samples were anesthetized and dissected as soon as possible, the luminal contents of recta, intestines and duodena were collected respectively into different Petri dishes, and examined with the help of a stereomicroscope (Leica S8AP0, Germany). The ciliates were collected with Pasteur micropipettes and washed twice in $0.65 \% \mathrm{NaCl}$ solution.

\subsection{Light microscopy}

Some specimens were fixed in $5 \%$ formalin for $10 \mathrm{~min}$ and soaked for about $30 \mathrm{~min}$ in $10 \%$ glycerin alcohol in a concave slide; the remaining specimens were fixed in Bouin's fluids and stained with a Protargol method [11].
Specimens were observed, measured and photographed using a microscope (Olympus BX53, Japan). All measurements are in micrometers.

\subsection{Scanning electron microscopy}

The fully washed specimens were fixed in $2.5 \%$ glutaraldehyde in $0.2 \mathrm{M}$ PBS ( $\mathrm{pH} 7.4$ ) on a clean glass slide $(1 \mathrm{~cm} \times 1 \mathrm{~cm})$, which was previously treated with $0.1 \%$ poly-L-Lysine and dried completely in the air at room temperature. After being washed with PBS 3 times, they were post-fixed in $1 \%$ osmium tetroxide at $4^{\circ} \mathrm{C}$ for $1 \mathrm{~h}$, followed by serial dehydration in acetone and critical point drying using the HCP-2 critical point dryer (Hitachi Science Systems, Japan). Subsequently, the glass slide was mounted on an aluminum-stub using a double-sided adhesive tape and sputter-coated with a thin layer of gold in IB-3 ion coater (Eiko Engineering, Japan), before observation and photography using a Quanta 200 SEM (FEI, Netherlands).

\subsection{Extraction of genomic DNA and PCR amplification}

About 50 individuals were harvested, suspended in lysis buffer (10 mM Tris-HCl, pH 8.0; 1 M EDTA, pH 8.0; $0.5 \%$ sodium dodecyl sulfate; $60 \mu \mathrm{g} / \mathrm{mL}$ proteinase $\mathrm{K}$ ), and incubated at $55^{\circ} \mathrm{C}$ for $12-20 \mathrm{~h}$. DNA was extracted using a standard phenol/chloroform method, precipitated with ethanol, and resuspended in TE buffer. Polymerase chain reaction (PCR) amplifications were carried out using forward primer (5'-AACCTGGTTGATCCTGCCAGT-3') and reverse primer (5'-TGATCCTTCTGCAGGTTCACCTAC-3') [23]. The following cycling conditions included $5 \mathrm{~min}$ initial denaturation at $94^{\circ} \mathrm{C}$; 35 cycles of $30 \mathrm{~s}$ at $95^{\circ} \mathrm{C}, 1 \mathrm{~min}$ at $56-60^{\circ} \mathrm{C}$, and $1-2 \mathrm{~min}$ at $72^{\circ} \mathrm{C}$; with a final extension of $10 \mathrm{~min}$ at $72^{\circ} \mathrm{C}$. The PCR products were isolated using $1 \%$ agarose gel electrophoresis and purified using the Agarose Gel DNA Purification Kit (TaKaRa Biotechnology, Dalian, Japan). The amplified fragment was cloned into a pMD ${ }^{\circledR} 18-\mathrm{T}$ vector (TaKaRa Biotechnology, Dalian) and sequenced in both directions using M13 forward and reverse primers on an ABI PRISM $^{\circledR} 3730$ DNA Sequencer (Applied Biosystems, USA). The SSU rRNA gene sequence of B. grimi was deposited in GenBank with accession number MG837094.

\subsection{Phylogenetic analysis}

Besides the SSU-rDNA sequence of B. grimi that we obtained in this study, other litostomatean sequences were retrieved from the GenBank/EMBL databases (Table 1). The sequence of Nyctotheroides deslierresae was used as the outgroup. The secondary structure-based SSU-rRNA sequence alignment of Litostomatea downloaded from the SILVA ribosomal RNA gene database project (https:// www.arb-silva.de/) [29] was used as the "seed" alignment to build a profile Hidden Markov Model (HMM) using HMMER Package, version 3.1. Then the HMM profile 
Table 1. List of sequences from GenBank/EMBL databases used for phylogenetic analysis.

\begin{tabular}{|c|c|c|}
\hline Species & $\begin{array}{l}\text { GenBank/EMBL } \\
\text { accession number }\end{array}$ & Reference \\
\hline \multicolumn{3}{|l|}{ Trichostomatia } \\
\hline \multicolumn{3}{|l|}{ Vestibuliferida } \\
\hline Balantidium polyvacuolum & KJ124724 & Li et al. [19] \\
\hline Balantidium ctenopharyngodoni & GU480804 & Li et al. [19] \\
\hline Balantidium entozoon & EU581716 & Grim and Buonanno [12] \\
\hline Balantidium duodeni & KM057846 & Chistyakova et al. [7] \\
\hline Balantidium grimi & MG837094 & present study \\
\hline \multirow[t]{2}{*}{ Balantioides coli (syn. Balantidium coli) } & AM982723 & Ponce-Gordo et al. [27] \\
\hline & AM982722 & Ponce-Gordo et al. [27] \\
\hline Dasytricha ruminantium & U57769 & Wright and Lynn [41] \\
\hline Isotricha intestinalis & U57770 & Wright and Lynn [41] \\
\hline Isotricha prostoma & AF029762 & Strüder-Kypke et al. [38] \\
\hline Helicozoster indicus & AB794981 & Ito et al. [14] \\
\hline Latteuria media & AB794983 & Ito et al. [14] \\
\hline Latteuria polyfaria & AB794982 & Ito et al. [14] \\
\hline Paraisotricha minuta & AB794984 & Ito et al. [14] \\
\hline Paraisotricha colpoidea & EF632075 & Strüder-Kypke et al. [37] \\
\hline Buxtonella sulcata & AB794979 & Ito et al. [14] \\
\hline \multicolumn{3}{|l|}{ Macropodiniida } \\
\hline Amylovorax dehorityi & AF298817 & Cameron et al. [4] \\
\hline Amylovorax dogieli & AF298825 & Cameron et al. [4] \\
\hline Bitricha tasmaniensis & AF298821 & Cameron et al. [4] \\
\hline Bandia cribbi & AF298824 & Cameron and O'Donoghue [5] \\
\hline Bandia deveneyi & AY380823 & Cameron and O'Donoghue [5] \\
\hline Polycosta turniae & AF298818 & Cameron et al. (unpublished) \\
\hline Macropodinium yalabense & AF042486 & Wright (unpublished) \\
\hline Macropodinium ennuensis & AF298820 & Cameron et al. $[6]$ \\
\hline \multicolumn{3}{|l|}{ Entodiniomorphida } \\
\hline Cycloposthium bipalmatum & AB530165 & Imai et al. (unpublished) \\
\hline Troglodytella abrassarti & AB437347 & Irbis et al. [13] \\
\hline Ophryoscolex purkynjei & U57768 & Wright and Lynn [42] \\
\hline Epidinium caudatum & U57763 & Wright and Lynn [42] \\
\hline Entodinium caudatum & U57765 & Wright et al. [43] \\
\hline Diplodinium dentatum & U57764 & Wright and Lynn [42] \\
\hline Polyplastron multivesiculatum & U57767 & Wright et al. [43] \\
\hline Eudiplodinium maggii & U57766 & Wright and Lynn [42] \\
\hline \multicolumn{3}{|l|}{ Haptoria } \\
\hline \multicolumn{3}{|l|}{ Haptorida } \\
\hline Dileptus sp. & $\mathrm{AF} 029764$ & Strüder-Kypke et al. [38] \\
\hline Homalozoon vermiculare & L26447 & Leipe et al. [17] \\
\hline Enchelys polynucleata & DQ411861 & Strüder-Kypke et al. [38] \\
\hline Spathidium stammeri & DQ411862 & Strüder-Kypke et al. [38] \\
\hline Didinium nasutum & U57771 & Wright and Lynn [41] \\
\hline \multicolumn{3}{|l|}{ Pleurostomatida } \\
\hline Amphileptus procerus ${ }^{*}$ & AY102175 & Zhu et al. (unpublished) \\
\hline Loxophyllum rostratum & DQ411864 & Strüder-Kypke et al. [38] \\
\hline \multicolumn{3}{|l|}{ Armophorea } \\
\hline \multicolumn{3}{|l|}{ Clevelandellida } \\
\hline Nyctotheroides deslierresae & AF145353 & Affa'a et al. [1] \\
\hline
\end{tabular}

\footnotetext{
submitted as Hemiophrys procera, according to Strüder-Kypke et al. [37].
} 
Table 2. Morphometric light microscopic parameters of B. grimi.

\begin{tabular}{|c|c|c|c|c|c|c|c|c|}
\hline Character & $\overline{\mathrm{X}}$ & M & Min & Max & $\mathrm{SD}$ & $\mathrm{SE}$ & $\mathrm{CV}(\%)$ & $\mathrm{N}$ \\
\hline Body length (Lb) & 96.5 & 95.1 & 79.6 & 121.5 & 9.65 & 1.76 & 10.0 & 30 \\
\hline Body width & 57.8 & 55.4 & 43.6 & 83.6 & 9.43 & 1.72 & 16.3 & 30 \\
\hline Vestibulum length (Lv) & 43.4 & 44.0 & 32.6 & 53.9 & 4.43 & 0.81 & 10.2 & 30 \\
\hline Vestibulum width & 4.7 & 4.7 & 3.9 & 5.9 & 0.44 & 0.08 & 9.4 & 30 \\
\hline Macronucleus length & 24.1 & 24.4 & 20.0 & 29.2 & 2.11 & 0.38 & 8.8 & 30 \\
\hline Macronucleus width & 16.0 & 16.1 & 12.4 & 19.3 & 1.88 & 0.34 & 11.8 & 30 \\
\hline Micronucleus diameter & 2.5 & 2.5 & 2.2 & 2.9 & 0.21 & 0.06 & 8.1 & 13 \\
\hline Contractile vacuole diameter & 13.7 & 13.5 & 12.4 & 15.4 & 1.08 & 0.38 & 7.9 & 8 \\
\hline $\mathrm{Lb} / \mathrm{Lv}$ & 2.2 & 2.3 & 1.7 & 2.7 & 0.23 & 0.04 & 10.5 & 30 \\
\hline Number of kineties on the left & 51.2 & 51 & 41 & 59 & 5.56 & 1.85 & 10.9 & 9 \\
\hline Number of kineties on the right & 61.1 & 62 & 52 & 67 & 5.21 & 1.74 & 8.5 & 9 \\
\hline
\end{tabular}

Measurements are in $\mu \mathrm{m} . \overline{\mathrm{X}}$ : arithmetic mean, M: median, Min: minimum, Max: maximum, SD: standard deviation, SE: standard error, CV: coefficient of variation, $\mathrm{N}$ : number of individuals investigated.

obtained was used to create an alignment of the 40 sequences using Hmmalign within the package. The masked regions that could not be aligned unambiguously were removed from the initial alignment using MEGA 6.0 [39]. A GTR $+\mathrm{I}+\mathrm{G}$ model was selected as the best model by the program jModelTest 2.1.10 [8] based on the AIC criterion, which was used for both Maximum Likelihood (ML) and Bayesian (BI) inference analysis. An ML tree was constructed with the RaxML program [35]. The reliability of internal branches was assessed using the nonparametric bootstrap method with 1,000 pseudoreplicates. A Bayesian analysis performed with MrBayes v3.2.6 [32] was run for 1,000,000 generations sampling every 1,000 generations. All trees below the observed stationary level were discarded as a burn-in of $25 \%$ of the generations.

\section{Results}

Ninety-eight individuals of $Q$. spinosa were examined in the present study and 34 were found to be infected with Balantidium grimi (prevalence, $34.7 \%$ ). These specimens were found mainly in the recta of frogs.

Balantidium grimi n. sp.

urn:lsid:zoobank.org:act:84E00073-0D0C-4166-8D8320BFCC43480E

Type host: Quasipaa spinosa David, 1875.

Prevalence: $34.7 \%$ (34 of 98) of $Q$. spinosa were infected.

Type locality: Lishui City $\left(27^{\circ} 25^{\prime}-28^{\circ} 57^{\prime} \mathrm{N}, 118^{\circ} 41^{\prime}-\right.$ $\left.120^{\circ} 26^{\prime} \mathrm{E}\right)$, Zhejiang Province, China.

Infection site: Rectum.

Type material: Holotype catalogued under No. IHB2017W005, paratype catalogued under No. IHB2017W006 with protargol stained and the rest of ciliates preserved in 100\% alcohol (Nos. LS001-002), 2.5\% glutaraldehyde (No. LS003) and Bouin's fluids (Nos. LS004-LS006) have been deposited in Key laboratory of
Aquaculture Disease Control, Ministry of Agriculture, Institute of Hydrobiology, Chinese Academy of Sciences, China.

Etymology: The new species was designated Balantidium grimi n. sp. in honor of the great contributions of Prof. J. Norman Grim to parasitic and symbiotic ciliates.

\subsection{Morphology under light microscope}

Organism long-oval in shape (Figures 1A, C and 2), measuring $79.6-121.5 \mu \mathrm{m} \quad(\overline{\mathrm{X}}=96.5 \mu \mathrm{m} ; \mathrm{n}=30)$ in length and 43.6-83.6 $\mu \mathrm{m}(\overline{\mathrm{X}}=57.8 \mu \mathrm{m})$ in width. Body partially flattened and thickly ciliated (Figures 1A, C and 2). The number of body kineties ranged from 93 to 125 , oriented mostly parallel to the cell's long axis. Of these, 41 to 59 were dorsal and 52 to 67 were ventral. Vestibulum "V"-shaped, 32.6-53.9 $\mu \mathrm{m}$ ( $\overline{\mathrm{X}}=43.43 \mu \mathrm{m}$, $\mathrm{n}=30$ ) in length, accounted for $3 / 8$ to $4 / 7$ of the body length (Figures 1B, D, E and 2), and 3.9-5.9 $\mu \mathrm{m}$ $(\overline{\mathrm{X}}=4.7 \mu \mathrm{m}, \mathrm{n}=30)$ in width. Macronucleus oval and lay obliquely almost near the middle of body (Figures 1C, E, F and 2), 20.0-29.2 $\mu \mathrm{m}(\overline{\mathrm{X}}=24.1 \mu \mathrm{m}$, $\mathrm{n}=30)$ in length and $12.4-19.3 \mu \mathrm{m} \quad(\overline{\mathrm{X}}=16.0 \mu \mathrm{m}$, $\mathrm{n}=30$ ) in width. Micronucleus spherical or somewhat oval near the macronucleus (Figures 1C, E, F and 2), measuring approximately $2.2-2.9 \mu \mathrm{m} \quad(\overline{\mathrm{X}}=2.5 \mu \mathrm{m}$, $\mathrm{n}=13$ ) in diameter. A distinct contractile vacuole situated at the posterior region of the body with 12.4$15.4 \mu \mathrm{m}(\overline{\mathrm{X}}=13.7 \mu \mathrm{m}, \mathrm{n}=8)$ in diameter (Figures $1 \mathrm{~A}$ and 2). A cytoproct present at the posterior end of the body (Figures $1 \mathrm{~A}$ and 2). Detailed morphometric parameters are presented in Table 2 .

\subsection{Morphology under scanning electron microscope}

B. grimi is thickly ciliated, but with uniform arrangement on the cell surface (Figures 3A, B). Regular beat patterns of cilia that look like "waves" make the cell move smoothly (Figure 3A). The "waves" and ridges 

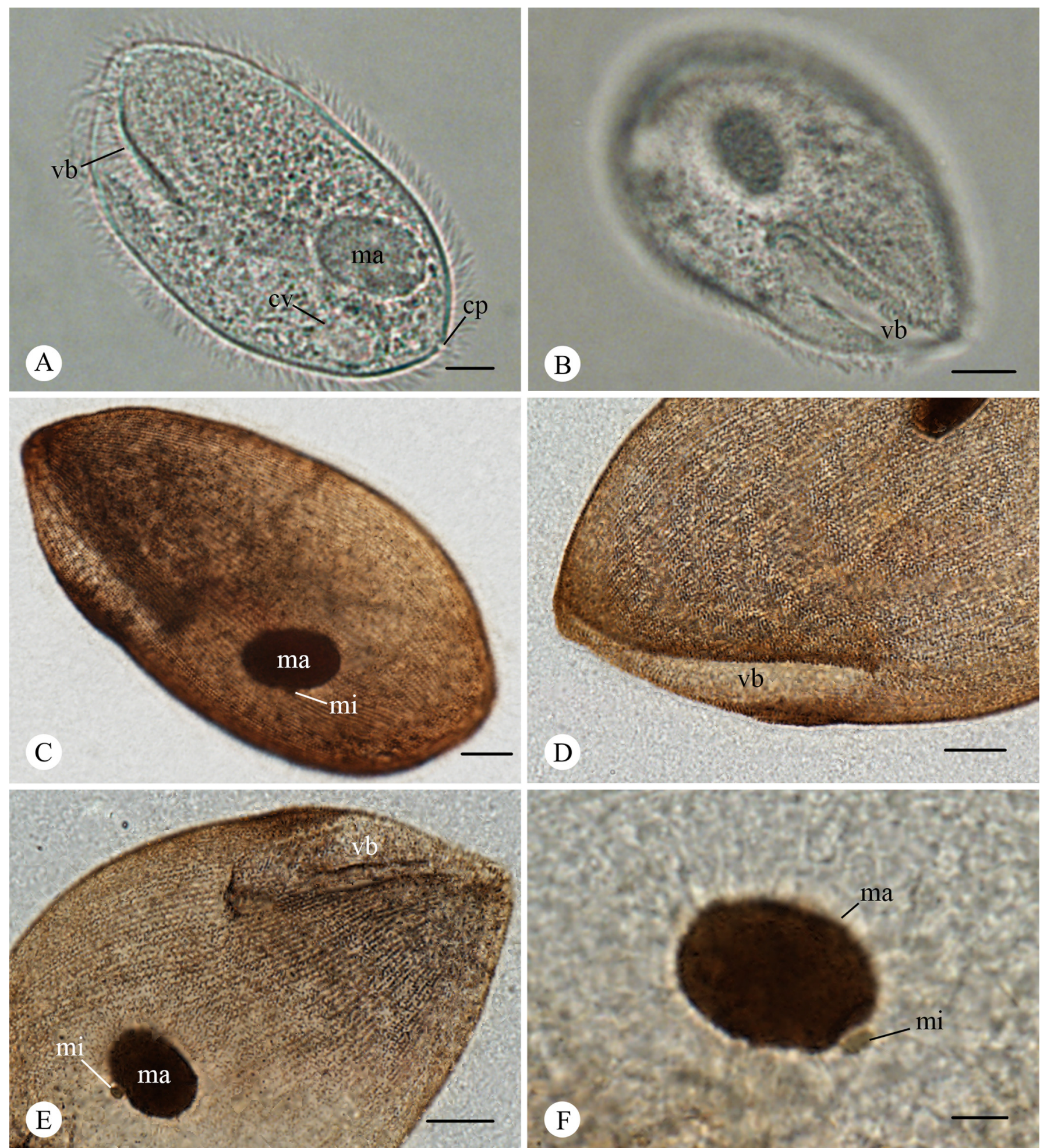

Figure 1. LM images of B. grimi. A. Specimens fixed in formalin (5\%) and soaked in glycerine-alcohol (10\%), showing the oval body shape, vestibulum (vb) and macronucleus (ma), a round contractile vacuole $(\mathrm{cv})$ in the posterior and a cytoproct $(\mathrm{cp})$ at the end of the body. Scale bar $=10 \mu \mathrm{m}$. B. Specimens fixed in formalin (5\%) and soaked in glycerine-alcohol (10\%), showing the long vestibulum (vb) surrounded by cilia. Scale bar $=10 \mu \mathrm{m}$. C-F. are protargol stained: C. showing the body shape, macronucleus (ma) and micronucleus (mi). Scale bar $=10 \mu \mathrm{m}$. D. showing the vestibulum and somatic kineties. Scale bar $=10 \mu \mathrm{m}$. E. showing the vestibulum (vb) and the oval macronucleus (ma) with a spherical micronucleus (mi) embedded in the middle. Scale bar $=10 \mu \mathrm{m}$. F. showing the relative position of macronucleus (ma) and micronucleus (mi). Scale bar $=5 \mu \mathrm{m}$. 


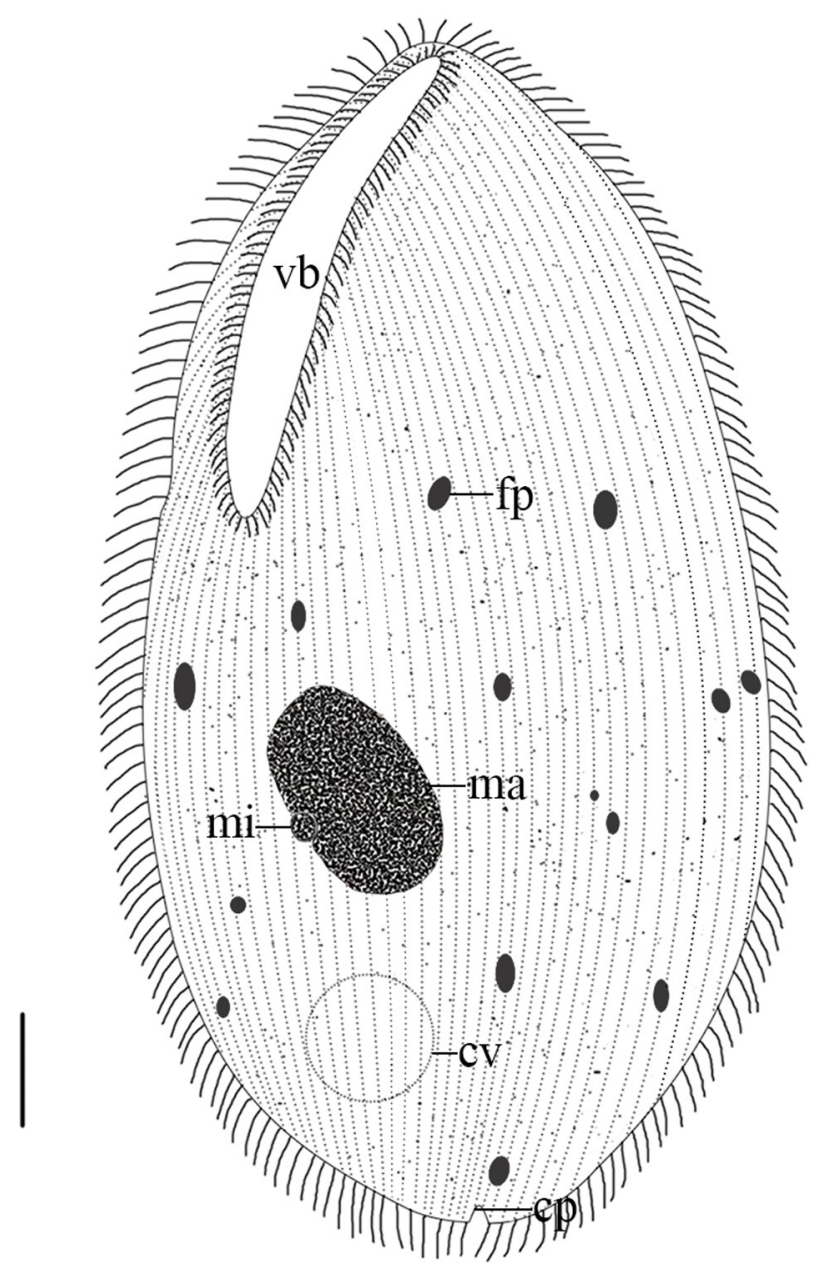

Figure 2. Schematic drawing of B. grimi, showing the general form and structures from the ventral-left view: vestibulum (vb), food particles (fp), macronucleus (ma), micronucleus (mi), contractile vacuole (cv) and cytoproct (cp). Scale bar $=10 \mu \mathrm{m}$.

formed an angle ranging from $0^{\circ}$ (at the posterior) to $60^{\circ}$ (at the anterior) (Figures 3A, C, D). Numerous cortical grooves arranged alternately with cortical ridges, which are parallel to the longitudinal axis of the body (Figure 3D). The cilia originate within grooves and are quite close together; those in Figure 3D are about $0.62 \mu \mathrm{m}$ apart.

\subsection{Phylogenetic analysis}

The sequenced SSU-rRNA gene of B. grimi is 1,640 bases in length and the guanine-cytosine (GC) content is $42.26 \%$. The topologies of our phylogenetic trees generated using MrBayes and PhyML algorithms are totally accordant (Figure 4). Species of the family Balantidiidae are separated into three clades. B. grimi grouped together with B.duodeni and the type species of the genus, B. entozoon, and form the first clade whose hosts are anuran amphibians (100\% ML, 1.00 BI). B. polyvacuolum and B. ctenopharyngodoni form the second balantidial clade inhabiting fish hosts. The third group consisted of two isolates of B. coli, which were reported from many mammalian hosts, including pigs and humans.

\section{Discussion}

A new Balantidium species inhabiting Chinese anuran amphibians Quasipaa spinosa is recorded herein. To our knowledge, this is the first report of Balantidium species in Q. spinosa.

B. grimi is quite unique considering its remarkably flattened body and conspicuous slit-shaped vestibulum, which can distinguish it from other Balantidium species [7,12,21]. B. grimi resembles B.entozoon, B.duodeni, $B$. helenae and B. sinensis in some aspects. For example, B. grimi shares a similar $\mathrm{Lv} / \mathrm{Lb}$ value with $B$. duodeni [7]. But in terms of body forms and dimensions, these two balantidial species could easily be discriminated from each other. As to the shape and dimension of the macronucleus, as well as the position of the contractile vacuole, B. grimi somewhat resembles $B$. helenae [33], but the latter species possesses a remarkable "knob" at the posterior end. Comparisons were also made between B.grimi and B. sinensis inhabiting the Chinese giant salamander Andrias davidianus [20] as well as B. entozoon, the type species of the genus Balantidium [12]. Detailed comparisons of morphometric parameters among corresponding Balantidium species are presented in Table 3.

According to the molecular phylogenetic analysis, the order Macropodiniida ciliates is closely related to fish balantidial species [14,19]. The affinity implies that macropodiniids may have been the result of separate invasions of terrestrial hosts by ciliates initially associated with aquatic hosts [19]. Macropodiniids, previously called "Australian clade", possess similar oral cavities to some vestibuliferids that are bordered by somatic kineties and analogous ultrastructure to the Isotrichidae $[5,21,37,38]$. Moreover, the strong molecular support of Macropodiniida assemblage as a sister clade to the Balantidiidae (fish balantidia) also gives us an indication that Macropodiniida ought to be incorporated into the order Vestibuliferida, which also coincides with the viewpoint of former studies $[5,14,19]$.

Our results show that the genus Balantidium is clearly polyphyletic and all Balantidium species are separated into three distinct clades, according to host specificity: fish balantidia (B. ctenopharyngodoni and B. polyvacuolum), amphibian balantidia (B. grimi, B. entozoon and B. duodeni), and balantidia from warm-blooded vertebrates (Balantioides coli) [7]. Pomajbíková et al. [26] has proposed a new genus Neobalantidium for the third group. However, it was recently suggested to reinstate the genus Balantioides as this taxon has been named for a long time [7]. Here, we accepted the generic name Balantioides to describe this group. As to the amphibian balantidia, our new species clustered with the other two species, B. entozoon and B.duodeni with maximum molecular supports. On this point, our results are consistent with 

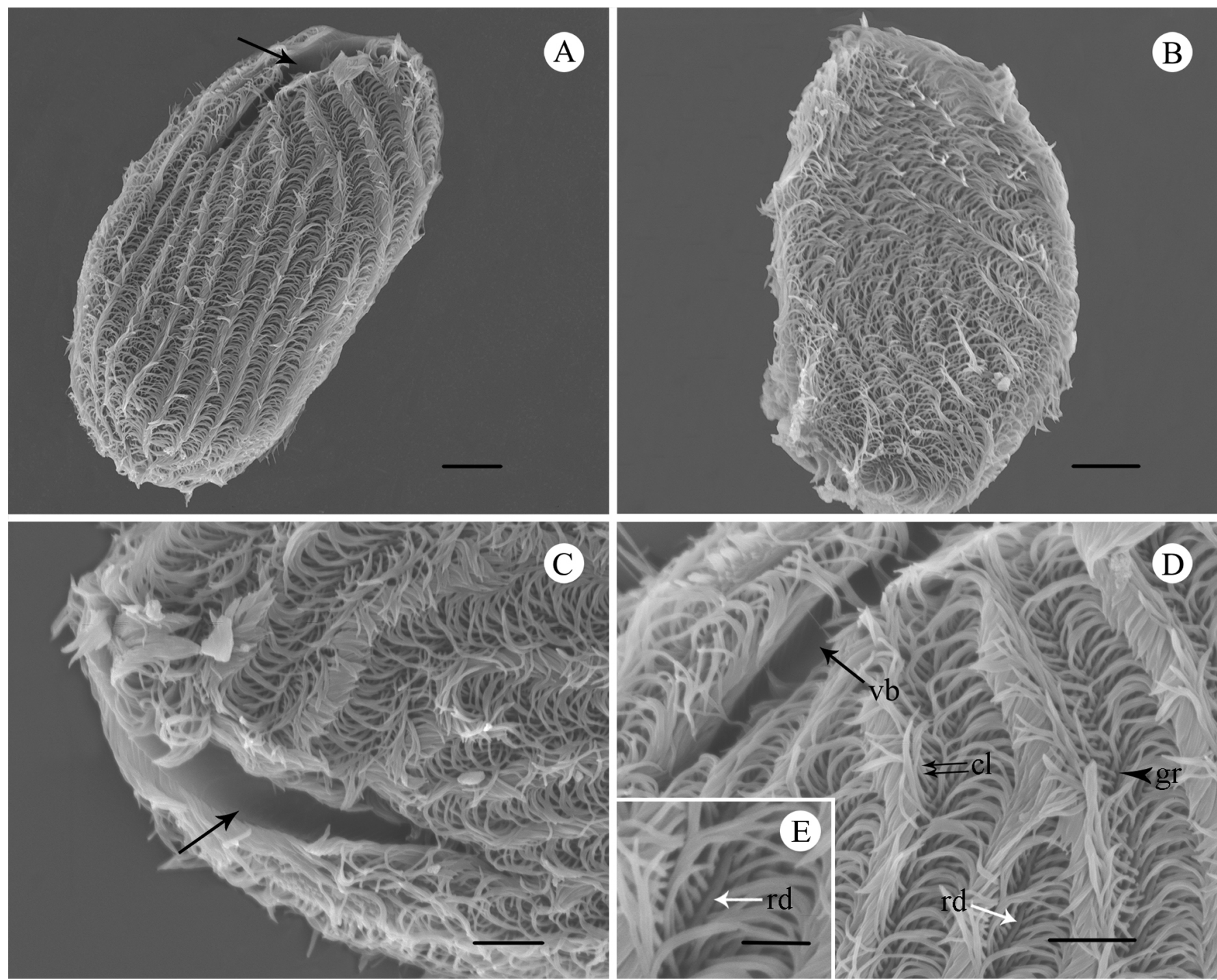

Figure 3. SEM images of B. grimi. A. Overview of the ventral-left side (oral side), showing the general form, vestibulum (arrow) and uniformly arranged cilia. Scale bar $=10 \mu \mathrm{m}$. B. Overview of the right side, showing the body surface is partially flattened and thickly ciliated. Scale bar $=10 \mu \mathrm{m}$. C. Ventral-left view of the "V"-shaped vestibulum (arrow). Scale bar $=5 \mu \mathrm{m}$. D. The left anterior area of ciliate, showing the vestibulum (vb), an interkinetal ridge ( $\mathrm{rd}$ ), the groove ( $\mathrm{gr}$ ) and the cilia (cl) extending from grooves and are close to one another. Scale bar $=5 \mu \mathrm{m}$. E. Selected enlargement of Figure 3D, showing a ridge (rd) between cilia. Scale bar $=2 \mu \mathrm{m}$.

Table 3. Comparison of body length (Lb), vestibulum length $(\mathrm{Lv})$ and the ratio of vestibulum length and body length (Lv/Lb) between B. grimi and four Balantidium species.

\begin{tabular}{|c|c|c|c|c|c|c|c|c|c|c|}
\hline \multirow[t]{2}{*}{ Species } & \multirow[t]{2}{*}{ Host } & \multicolumn{3}{|c|}{ Body length (Lb) } & \multicolumn{3}{|c|}{ Vestibulum length (Lv) } & \multicolumn{3}{|c|}{$\mathrm{Lv} / \mathrm{Lb}$} \\
\hline & & $\overline{\mathrm{X}}$ & Min & Max & $\overline{\mathrm{X}}$ & Min & Max & $\overline{\mathrm{X}}$ & Min & Max \\
\hline Balantidium entozoon & Rana esculenta & 83.3 & 60.0 & 129.0 & 27.7 & 20.0 & 34.0 & 0.33 & 0.19 & 0.48 \\
\hline Balantidium duodeni & Rana temporaria & 128.6 & 111.6 & 156.9 & 56.3 & 44.2 & 76.7 & 0.44 & 0.40 & 0.60 \\
\hline Balantidium helenae & Rana ridibunda & 88.9 & 62.5 & 112.5 & 33.2 & 25.0 & 50.0 & 0.37 & 0.29 & 0.52 \\
\hline Balantidium sinensis & Andrias davidianus & 138.3 & 120.0 & 158.4 & 47.0 & 40.8 & 52.8 & 0.34 & 0.30 & 0.44 \\
\hline Balantidium grimi & Quasipaa spinosa & 96.5 & 79.6 & 121.5 & 43.4 & 32.6 & 53.9 & 0.44 & 0.37 & 0.58 \\
\hline
\end{tabular}

Measurements are in $\mu \mathrm{m} . \overline{\mathrm{X}}$ : arithmetic mean, Min: minimum, Max: maximum. 


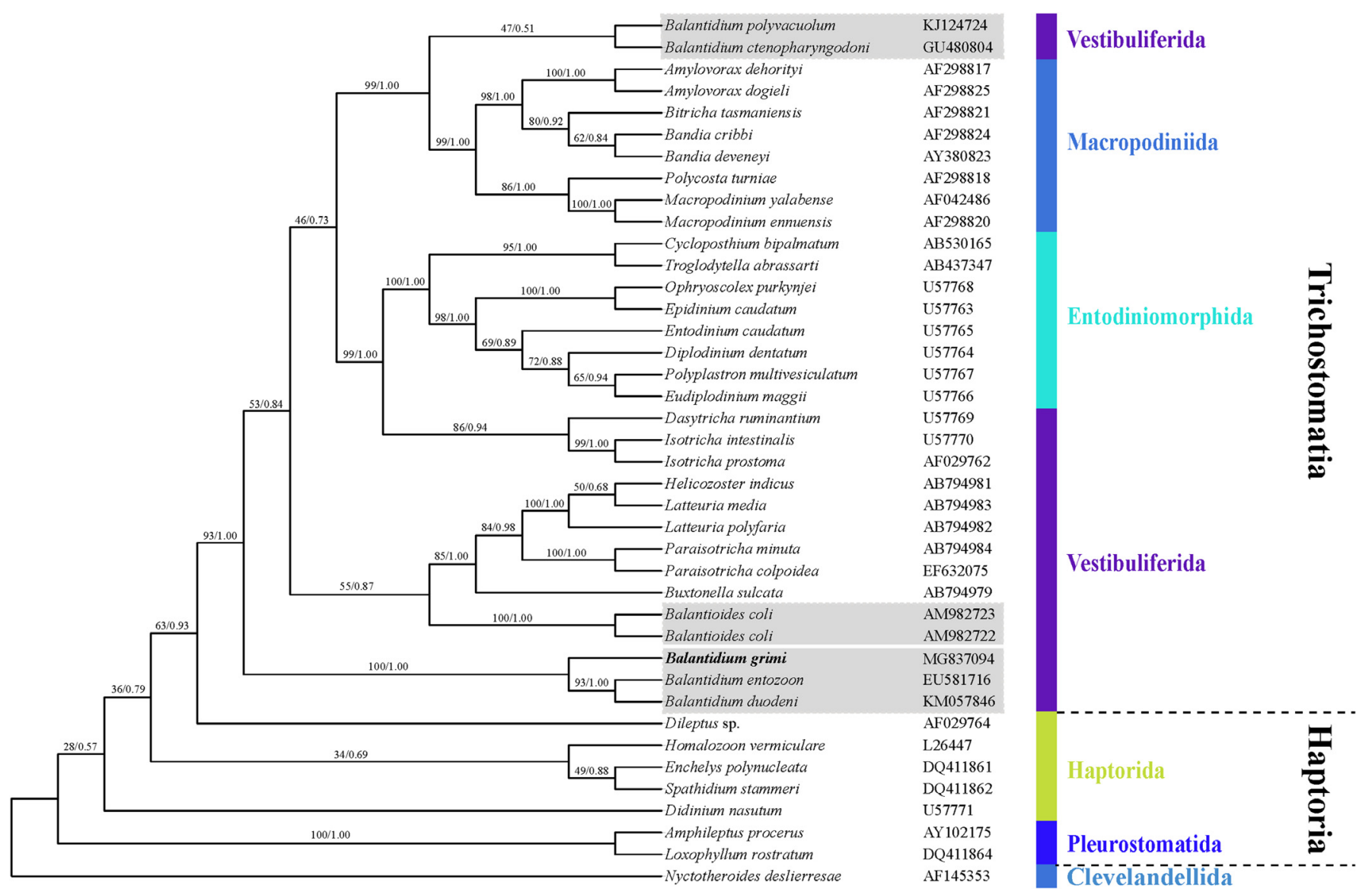

Figure 4. Phylogenetic relationships of the SSU-rRNA sequences of B. grimi marked in bold and other Trichostomatia species showing the position of $B$. grimi inferred by maximum likelihood method and Bayesian algorithm. The trees were rooted using the sequence of Nyctotheroides deslierresae as the outgroup taxa. Numbers at nodes indicate bootstrap percentage and posterior probability, respectively. The sequences corresponding to species of the genus Balantidium are shadowed.

those of Chistyakova et al. [7], but differ from those of Li et al. [19]. We suspect that the key reason for this disagreement is the quantity of introduced species used for phylogenetic analysis. The greater the number of related species studied, the greater the accuracy of the resulting phylogeny. Thus, more molecular information on Balantidium species from fishes and amphibians as well as reptiles is needed to clarify their phylogenetic relationships.

Acknowledgments. Financial support for this study was provided by the National Natural Science Foundation of China (No. 31772429, 31471978), the Youth Innovation Promotion Association CAS (No. Y82Z01), and the Earmarked Fund for China Agriculture Research System (No. CARS-45-15).

\section{Conflict of interest}

The authors declare that they have no competing interests.

\section{References}

1. Affa'a FL, Hickey DA, Strüder-Kypke M, Lynn DH. 2004. Phylogenetic position of species in the genera Anoplophrya, Plagiotoma, and Nyctotheroides (Phylum Ciliophora), endosymbiotic ciliates of annelids and anurans. Journal of Eukaryotic Microbiology, 51(3), 301-306.

2. Bezzenberger E. 1904. Über Infusorien aus asiatischen Anuren. Archiv für Protistenkunde, 3, 138-174.

3. Bhatia BL, Gulati AN. 1927. On some parasitic ciliates from Indian frogs, toads, earthworms and cockroaches. Archiv für Protistenkunde, 57, 85-120.

4. Cameron SL, Adlard RD, O'Donoghue PJ. 2001. Evidence for an independent radiation of endosymbiotic litostome ciliates within Australian marsupial herbivores. Molecular Phylogenetics and Evolution, 20(2), 302-310.

5. Cameron SL, O'Donoghue PJ. 2004. Phylogeny and biogeography of the "Australian" trichostomes (Ciliophora: Litostomata). Protist, 155(2), 215-235.

6. Cameron SL, Wright A-DG, O'Donoghue PJ. 2003. An expanded phylogeny of the Entodiniomorphida (Ciliophora: Litostomatea). Acta Protozoologica, 42(1), 1-6. 
7. Chistyakova LV, Kostygov AY, Kornilova OA, Yurchenko V. 2014. Reisolation and redescription of Balantidium duodeni Stein, 1867 (Litostomatea, Trichostomatia). Parasitology Research, 113(11), 4207-4215.

8. Darriba D, Taboada GL, Doallo R, Posada D. 2012. jModelTest 2: more models, new heuristics and parallel computing. Nature Methods, 9(8), 772.

9. Ehrenberg CG. 1838. Die infusionsthierchen als vollkommene organismen. Leipzig: Leopold Voss. p. 612.

10. Ghosh EN. 1921. Infusoria from the environment of Calcutta. I. Bulletin of the Carmichael Medical College, Calcutta, 2, 6-17.

11. Grim JN. 1988. A somatic kinetid study of the pycnotrichid ciliate Vestibulongum corlissi NG, N. Sp. (Class: Litostomatea), symbiont in the intestines of the surgeonfish, Acanthurus xanthopterus. Journal of Eukaryotic Microbiology, 35(2), 227-230.

12. Grim JN, Buonanno F. 2009. A re-description of the ciliate genus and type species, Balantidium entozoon. European Journal of Protistology, 45(3), 174-182.

13. Irbis C, Garriga R, Kabasawa A, Ushida K. 2008. Phylogenetic analysis of Troglodytella abrassarti isolated from Chimpanzees (Pan troglodytes verus) in the wild and in captivity. Journal of General and Applied Microbiology, 54 (6), 409-413.

14. Ito A, Ishihara M, Imai S. 2014. Bozasella gracilis n. sp. (Ciliophora, Entodiniomorphida) from Asian elephant and phylogenetic analysis of entodiniomorphids and vestibuliferids. European Journal of Protistology, 50(2), 134-152.

15. Jírovec O. 1930. Über ein neues Balantidium aus dem Darmtraktus von Amblystoma tigrinum. Zeitschrift für Parasitenkunde, 3(1), 17-21.

16. Khan MM, Ip YK. 1986. Parasites of toads from Singapore, with a description of Balantidium singaporensis $\mathrm{sp}$. n. (Ciliophora: Balantidiidae). Zoological Science, 3(3), 543546.

17. Leipe DD, Bernhard D, Schlegel M, Sogin ML. 1994. Evolution of 16S-like ribosomal RNA genes in the ciliophoran taxa Litostomatea and Phyllopharyngea. European Journal of Protistology, 30(3), 354-361.

18. Li M, Li W, Zhang L, Wang C. 2013. Balantidium honghuensis n. sp. (Ciliophora: Trichostomatidae) from the rectum of Rana nigromaculata and R. limnocharis from Honghu Lake, China. Korean Journal of Parasitology, 51 (4), 427-431.

19. Li M, Ponce-Gordo F, Grim JN, Wang C, Nilsen F. 2014. New insights into the molecular phylogeny of Balantidium (Ciliophora, Vetibuliferida) based on the analysis of new sequences of species from fish hosts. Parasitology Research, 113(12), 4327-4333.

20. Li M, Wang J, Zhang J, Gu Z, Ling F, Ke X, Gong X. 2008. First report of two Balantidium species from the Chinese giant salamander, Andrias davidianus: Balantidium sinensis Nie 1935 and Balantidium andianusis n. sp. Parasitology Research, 102(4), 605-611.

21. Lynn D. 2008. The ciliated protozoa: characterization, classification, and guide to the literature. Dordrecht: Springer Science \& Business Media. p. 373.

22. Mahoon MS, Khan MI. 1986. Entozoic protozoa of frog Rana cyanophlyctis Schneider. Biologia (Lahore), 32(32), 383-420.

23. Medlin L, Elwood HJ, Stickel S, Sogin ML. 1988. The characterization of enzymatically amplified eukaryotic $16 \mathrm{~S}-$ like rRNA-coding regions. Gene, 71(2), 491-499.

24. Nie D. 1932. Intestinal ciliates of Amphibia of Nanking. Science Society of China: Nanking.
25. Pal NL, Dasgupta B. 1978. Observations on two new species of Balantidium in the Indian salamander, Tylototriton verrucosus (Caudata: Salamandridae). Proceedings of the Zoological Society, 31, 47-52.

26. Pomajbíková K, Oborník M, Horák A, Petrželková KJ, Grim JN, Levecke B, Todd A, Mulama M, Kiyang J, Modrý D. 2013. Novel insights into the genetic diversity of Balantidium and Balantidium-like cyst-forming ciliates. PLoS Neglected Tropical Diseases, 7(3), e2140.

27. Ponce-Gordo F, Jimenez-Ruiz E, Martinez-Diaz R. 2008. Tentative identification of the species of Balantidium from ostriches (Struthio camelus) as Balantidium coli-like by analysis of polymorphic DNA. Veterinary Parasitology, 157 (1), 41-49.

28. Puytorac PD, Grain J. 1965. Structure et ultrastructure de Balantidium xenopi sp. nov. Cilié trichostome parasite du batracien Xenopus fraseri Boul. Protistologica, 1, 29-36.

29. Quast C, Pruesse E, Yilmaz P, Gerken J, Schweer T, Yarza P, Peplies J, Glöckner FO. 2012. The SILVA ribosomal RNA gene database project: improved data processing and web-based tools. Nucleic Acids Research, 41(D1), D590D596.

30. Ray H. 1932. On the morphology of Balantidium sushilii $\mathrm{n}$. sp., from Rana Tigrina Daud. Journal of Microscopy, 52(4), 374-382.

31. Rodriguez JM. 1939. On the morphology of Balantidium kirbyi n. sp., from the Plathander. Journal of Parasitology, 25(3), 197-201.

32. Ronquist F, Teslenko M, Van Der Mark P, Ayres DL, Darling A, Höhna S, Larget B, Liu L, Suchard MA, Huelsenbeck JP. 2012. MrBayes 3.2: efficient Bayesian phylogenetic inference and model choice across a large model space. Systematic Biology, 61(3), 539-542.

33. Senler NGL, Yildiz İ. 2000. The ciliate fauna in the digestive system of Rana ridibunda (Amphibia: Anura) I: Balantidium (Balantidiidae, Trichostomatida). Turkish Journal of Zoology, 24(1), 33-44.

34. Shete SG, Krishnamurthy R. 1984. Observations on the rectal ciliates of the genus Balantidium, Claparede and Lachmann, 1858 from Indian amphibians Rana tigrina and R.cyanophlyctis. Archiv für Protistenkunde, 128(1-2), 179-194.

35. Stamatakis A. 2014. RAxML version 8: a tool for phylogenetic analysis and post-analysis of large phylogenies. Bioinformatics, 30(9), 1312-1313.

36. Stein F. 1867. Der Organismus der Infusionsthiere nach eigenen Forschungen in systematischer Reihenfolge bearbeitet: Leipzig.

37. Strüder-Kypke MC, Kornilova OA, Lynn DH. 2007. Phylogeny of trichostome ciliates (Ciliophora, Litostomatea) endosymbiotic in the Yakut horse (Equus caballus). European Journal of Protistology, 43(4), 319-328.

38. Strüder-Kypke MC, Wright A-DG, Foissner W, Chatzinotas A, Lynn DH. 2006. Molecular phylogeny of litostome ciliates (Ciliophora, Litostomatea) with emphasis on freeliving haptorian genera. Protist, 157(3), 261-278.

39. Tamura K, Stecher G, Peterson D, Filipski A, Kumar S. 2013. MEGA6: molecular evolutionary genetics analysis version 6.0. Molecular Biology and Evolution, 30(12), 2725-2729.

40. Walker EL. 1909. Sporulation in the parasitic Ciliata. Archiv für Protistenkunde, 17, 297.

41. Wright A-DG, Lynn DH. 1997. Monophyly of the trichostome ciliates (Phylum Ciliophora: Class Litostomatea) tested using new 18S rRNA sequences from the vestibuliferids, Isotricha intestinalis and Dasytricha ruminantium, and the haptorian, Didinium nasutum. European Journal of Protistology, 33(3), 305-315. 
42. Wright A-DG, Lynn DH. 1997. Phylogenetic analysis of the rumen ciliate family Ophryoscolecidae based on $18 \mathrm{~S}$ ribosomal RNA sequences, with new sequences from Diplodinium, Eudiplodinium, and Ophryoscolex. Canadian Journal of Zoology, 75(6), 963-970.
43. Wright ADG, Dehority BA, Lynn DH. 1997. Phylogeny of the rumen ciliates Entodinium, Epidinium and Polyplastron (Litostomatea: Entodiniomorphida) inferred from small subunit ribosomal RNA sequences. Journal of Eukaryotic Microbiology, 44(1), 61-67.

Cite this article as: Zhao W, Li C, Zhang D, Wang R, Zheng Y, Zou H, Li W, Wu S, Wang G, Li M. 2018. Balantidium grimin. sp. (Ciliophora, Litostomatea), a new species inhabiting the rectum of the frog Quasipaa spinosa from Lishui, China. Parasite 25, 29

\section{- PARASTE}

Reviews, articles and short notes may be submitted. Fields include, but are not limited to: general, medical and veterinary parasitology; morphology, including ultrastructure; parasite systematics, including entomology, acarology, helminthology and protistology, and molecular analyses; molecular biology and biochemistry; immunology of parasitic diseases; host-parasite relationships; ecology and life history of parasites; epidemiology; therapeutics; new diagnostic tools.

All papers in Parasite are published in English. Manuscripts should have a broad interest and must not have been published or submitted elsewhere. No limit is imposed on the length of manuscripts.

Parasite (open-access) continues Parasite (print and online editions, 1994-2012) and Annales de Parasitologie Humaine et Comparée (1923-1993) and is the official journal of the Société Française de Parasitologie. 